\title{
Leadership Style and Performance Analysis Over The Regent of Pohuwato District, Gorontalo Province
}

\author{
$1^{\text {st }}$ Gretty Syatiani Saleh \\ Postgraduate, Universitas Negeri \\ Makassar \\ Makassar, Indonesia \\ grettysyatrianisaleh1@gmail.com
}

\author{
$2^{\text {nd }}$ Rifdan \\ Postgraduate Universitas Negeri \\ Makassar \\ Makassar, Indonesia
}

\author{
$3^{\text {rd Jasruddin Mahande }}$ \\ Postgraduate, Universitas Negeri \\ Makassar \\ Makassar, Indonesia
}

\begin{abstract}
This study aims to describe (1) transformational leadership style (2) transactional leadership style, (3) Regent's performance and (4) Pohuwato Regent's strategy model in Gorontalo Province in running government and development. This study uses a quantitative descriptive approach with a sample of 134 civil servants (PNS) distributed in proportionate stratified random. Data collection used a questionnaire that was then analysed with descriptive statistics. The results showed that: (1) the Regent's transformational leadership style in running the Government and development of the Pohuwato Regency in Gorontalo Province was very high or very good, (2) The Regent's transactional leadership style in running the Government and development of Pohuwato Regency in Gorontalo Province was categorized as high or well, (3) the performance of the Regent in running the government and regional development of the Pohuwato Regency in Gorontalo Province is very high or very good and (4) a strategy model to ensure effective governance and development by implementing transactional and transformational leadership styles effectively and achieving performance optimally.
\end{abstract}

Keywords-Transformational, transactional, Regent's performance

\section{INTRODUCTION}

Partial tasks and authorities of government affairs are handed over to the regions through decentralization of authority and by strengthening regional autonomy, demands openness, accountability, responsiveness, and creativity from all state apparatus (Decree Number 32 of 2004). The goal of implementing the country is the creation of good, clean, authoritative, professional and responsible governance, which is realized by efficient and effective bureaucratic figures and behavior and can provide excellent service to the entire community.

Pohuwato Regency in Gorontalo Province is one of the districts with a very strategic position regarding social, economic and political interests. Pohuwato Regency deserves to expand the quantity of its development and the quality of community resources in providing services to the community. Based on the Report on Accountability Statement of the Pohuwato Regency Regional Government in 2014 and 2015 many weaknesses have not been able to fulfil the implementation of equitable development and optimal implementation of governance as expected by the community. This was confirmed by the Education Fund management institution (LPDP) of the Ministry of Finance of the Republic of Indonesia which refers to the list of Disadvantaged Areas and Border Areas of the Directorate of Special Regions and Disadvantaged Regions, Ministry of National Development Planning (PPN) / National Development Planning Agency (BAPPENAS) based on letter no 2421 / Dt.7.2 / 04/2015 dated April 21, 2015, where Pohuwato Regency is one of the lagging regions of the three lagging regions in Gorontalo province. The Indonesian public sector is still experiencing problems in supporting the delivery of quality public services [1]. Nevertheless, the performance of the Pohuwato Regency Government based on the Pohuwato District LKPJ in 2016 has increased. Various achievements were made by the Regent in governance.

In essence, governance is aimed at creating public service functions. Good governance tends to create good public service functions. The principle of good governance is not only limited to the use of applicable laws and regulations, but is developed by applying the principles of good governance which do not only involve the government or state but must involve stakeholders outside the bureaucracy. Thus the ability of the leadership as a determinant of the direction to be achieved in the future is a very important stock in the life of the organization.

The role of the leader in improving the performance of local government bureaucracy is very significant. The role of the leader consists of three main aspects, namely (1) leader as a designer, leader as steward, and leader as a teacher [2]. The leadership style displayed by leaders in the public sector is a phenomenon of society, nationality, and state that influences the development of patterns and directions of social life, nationality, and statehood. Leadership is also a function that can encourage the realization of national ideals and goals, as well as aspirations that develop in the community, which arise due to the interaction between leaders and followers.

The success of leaders in improving the performance of their members in providing public services is highly dependent on their behavior in carrying out leadership functions in their leadership strategies [3]-[5] Leadership style is closely related to the decision-making process that must be carried out by leaders [6]. 
The application of the concept of leadership, both transactional leadership, and transformational leadership, is expected to increase the role of followers to do work in line with expectations. Transactional leadership and transformational leadership are carried out simultaneously for the achievement of goals or tasks [7]-[10]. The application of transactional leadership and transformational leadership is able to increase motivation, job satisfaction, commitment, to improve performance [11]-[14].

Furthermore, measuring the performance of public services of government agencies is very important to ensure that governance runs well. Performance is the work quality and quantity achieved by an employee in carrying out their duties following the responsibilities assigned to him [15]. More specifically, it is stated that the performance of the Regional Government is the achievement of the implementation of regional government affairs (Government Regulation of the Republic of Indonesia No. 6 of 2008). Previous statements indicate that the performance of local governments can be seen from the achievements obtained by one regional apparatus in carrying out the governance process both in quality and quantity.

A Mandate for Strategic Planning and Performance Measurement [16]. This opinion shows that performance measurement/assessment is a management tool to improve the quality of decision making and accountability. Continuous performance measurement will provide feedback, so that continuous improvement effort are objectively achieved in a certain period. Performance appraisal is one of the key factors for developing an organization effectively and efficiently. Comprehensive measures in the public sector include (1) Convenience; (2) Security; (3) Reliability; (4) Personal attention; (5) ProblemSolving approach; (6) Fairness; (7) Fiscal responsibility; (8) Citizen influence [17]. The existence of a work performance assessment policy or program means that the organization has made good use of existing human resources in the organization.

Some of the research descriptions above show the leadership style variables and the Regents's performance can ensure that the implementation of government runs effectively. The leadership style and performance of the Regents determine the characteristics of local governments in implementing development and governance. The results of the relevant research study confirm those leadership style variables which include transactional leadership style and transformational leadership are important factors in ensuring governance and development. The results of relevant research studies also show that performance achievement is a measure in ensuring that the government system in implementing governance and development has been effective.

However, previous research used leadership style and performance variables in analyzing governance and development separately. Therefore, this study will explore the style of leadership and performance of the Regent in carrying out government and development. Very interesting leadership and performance styles were analyzed because very few researchers studied them, especially in two aspects of leadership style simultaneously especially in Pohuwato District in Gorontalo Province

This study aims to illustrate the quality of the leadership style used by the regent as well as the achievement of performance in carrying out the Government and Development of the Pohuwato Regency in Gorontalo Province. The implication of the results of this study can be a reference in improving the quality of service to the community by using the right leadership style model and improving performance according to the needs of the Pohuwato Regency community in Gorontalo Province.

\section{RESEARCH METHODS}

This study uses descriptive quantitative research, with the consideration that this research attempts to describe events or events that have occurred in the present in the form of meaningful numbers. This research was conducted in Pohuwato Regency in Gorontalo Province, Indonesia. The study population was employees of the Pohuwato Regency Regional Government of Gorontalo Province who had group IV (not including teachers/overseers) totaling 267 people. The sampling technique used proportionate stratified random sampling with an error rate of 5\% so that 134 samples were found (Sugiyono, 2014)

Data collection techniques in this study used a questionnaire that contains statements related to transformational style, transactional leadership style, and performance. The instrument uses a rating scale model 1-4. Data analysis techniques using descriptive analysis. Data analysis techniques using descriptive analysis to determine the characteristics of each variable and can carry out an objective representation of research problems based on the achievement of respondents' score (employee). Descriptive analysis was carried out with the help of IBM SPSS statistical software 20. Assessment categorization of each aspect/variable refers to Azwar's (2014: 147) categorization.

\section{RESULTS AND DISCUSSION}

The administration and development of Pohuwato Regency in Gorontalo Province can be reviewed through transformational style, transactional leadership style, and Regents performance.

\section{A. Transformational leadership style}

Classification of employee perceptions of the attitude of the transactional leadership shown by the Regent in carrying out the governance and development of Pohuwato District in Gorontalo Province refers to [18] as follows. 
TABLE 1. TRANSFORMATIONAL LEADERSHIP SCORE CATEGORIZATION

\begin{tabular}{ccc}
\hline Category & Frequency & Percentage \\
\hline Very High & 63 & 53 \\
Height & 71 & 47 \\
Low & 0 & 0 \\
Very Low & 0 & 0 \\
Total & 134 & $100 \%$ \\
\hline
\end{tabular}

Table 1 is data on employee perceptions regarding the Regent's transformational leadership style. These data show that $53 \%$ of employees consider the Regent's transformational leadership to be in the highest category and $47 \%$ of employees consider the Regent's transformational leadership to be in the very high category. This data confirms that in general the Regent's transformational leadership style in running the government and development of Pohuwato Regency in Gorontalo Province is categorized as high and very high, which means that the transformational leadership shown by the Regents has proceeded very well.

Transformational leadership styles can be traced through aspects of inspiration motivation, charisma, individualized consideration and intellectual stimulation which can be seen visually in the following table.

TABLE 2. DATA ON THE PERCENTAGE OF TRANSFORMATIONAL LEADERSHIP

\begin{tabular}{lcccc}
\hline \multirow{1}{*}{ Aspect } & \multicolumn{4}{c}{ Percentage } \\
\cline { 2 - 5 } & $\begin{array}{c}\text { Sangat } \\
\text { Tinggi }\end{array}$ & Tinggi & Rendah & $\begin{array}{c}\text { Sangat } \\
\text { Rendah }\end{array}$ \\
$\begin{array}{l}\text { inspiration } \\
\text { motivation }\end{array}$ & 89,6 & 10,4 & 0 & 0 \\
$\begin{array}{l}\text { charisma } \\
\text { individualized } \\
\text { consideration }\end{array}$ & 25,4 & 74,6 & 0 & 0 \\
$\begin{array}{l}\text { intellectual } \\
\text { stimulation }\end{array}$ & 27,6 & 56 & 14,9 & 1,5 \\
\hline
\end{tabular}

Table. 1 shows data on employee perceptions related to transformational leadership in aspects of inspiration motivation, charisma, individualized consideration and intellectual stimulation. Employee perception data related to the Regent's personal transformational leadership in the aspect of inspiration motivation shows that $10.4 \%$ of employees respond in the high category and $89.6 \%$ of employees respond in the very high category. In the charism aspect, it shows that $25.4 \%$ of employees responded in a high category and $74.6 \%$ of employees gave a very high category response. In the aspect of individualized consideration shows that $6 \%$ of employees respond in the very low category; $26.1 \%$ of employees respond in the low category; $55.2 \%$ of employees responded with a high category, and $12.7 \%$ of employees responded with a very high category. In the aspect of intellectual stimulation shows that $1.5 \%$ of employees respond in a very low category; $14.9 \%$ of employees responded in the low category; $56 \%$ of employees responded in the high category, and $27.6 \%$ of employees responded in the very high category.

The results of the analysis show that the Regent's transformational leadership style is very good in running the government and development of the Pohuwato Regency in Gorontalo Province. High or good transformational leadership style is strongly influenced by the dimensions of inspiration motivation, in terms of planning with subordinates and charismatic dimensions of self-confidence in change. However, the aspects of individualized consideration and intellectual stimulation are still not good according to employee responses.

\section{B. Transactional leadership style}

Classification of employee perceptions of the attitude of the transactional leadership shown by the Regent in carrying out the governance and development of Pohuwato District in Gorontalo Province.

TABLE 3. TRANSACTIONAL LEADERSHIP SCORE CATEGORIZATION

\begin{tabular}{ccc}
\hline Category & Frequency & Percentage \\
\hline Very High & 3 & 2 \\
Height & 67 & 50 \\
Low & 64 & 48 \\
Very Low & 0 & 0 \\
Total & 134 & $100 \%$ \\
\hline
\end{tabular}

Figure 2 is data on employee perceptions related to the Regent's transactional leadership style. The data shows that $2 \%$ of employees consider the Regents's transactional leadership to be in the very high category, $50 \%$ of employees consider the Regents's transactional leadership to be in the high category and $48 \%$ of employees consider the Regents's transactional leadership to be in a low category. This data shows that in general the Regents's transactional leadership style in carrying out the governance and development of Pohuwato District in Gorontalo Province is categorized as high. However, there are still percentages that fall into the very high and low categories.

Transactional leadership styles can be traced through contingent reward aspects, laissez-faire, active management by exception and passive management bye exceptions that can be seen visually in the following table. 
TABLE 4. DATA ON THE PERCENTAGE OF TRANSACTIONAL LEADERSHIP

\begin{tabular}{lcccc}
\hline \multirow{2}{*}{\multicolumn{1}{c}{ Aspect }} & \multicolumn{3}{c}{ Percentage } \\
\cline { 2 - 5 } & $\begin{array}{l}\text { Very } \\
\text { High }\end{array}$ & High & Low & $\begin{array}{c}\text { Very } \\
\text { Low }\end{array}$ \\
contingen reward & 4,5 & 45,5 & 40,3 & 9,7 \\
$\begin{array}{l}\text { laissez-faire } \\
\text { active }\end{array}$ & 2,2 & 29,9 & 52,2 & 18,7 \\
$\begin{array}{l}\text { management by } \\
\text { exception }\end{array}$ & 2,2 & 34,2 & 61,2 & 2,3 \\
$\begin{array}{l}\text { passive } \\
\text { management bye } \\
\text { exception }\end{array}$ & 71,6 & 17,9 & 9 & 1,5 \\
\hline
\end{tabular}

Table.4 shows employee perception data related to transactional leadership style on contingent reward aspects, laissez-faire, active management by exception and passive management by exception. Employee perception data related to the Regent's transactional leadership in the contingent reward aspect showed that $9.7 \%$ of employees responded in the very low category; $40.3 \%$ of employees respond in the low category; $45.5 \%$ of employees responded with a high category and $4.5 \%$ of employees responded with a very high category. In the aspect of laizes fairez shows that $18.7 \%$ of employees respond in the very low category; $52.2 \%$ of employees respond in the low category; $29.9 \%$ of employees responded with a high category and $2.2 \%$ of employees responded with a very high category. The active management by exception aspect shows that $2.3 \%$ of employees respond in the very low category; $61.2 \%$ of employees responded in the low category; $34.2 \%$ of employees responded in the high category and $2.2 \%$ of employees responded in the very high category. The passive management bye exception aspect shows that $1.5 \%$ of employees respond in the very low category; $9 \%$ of employees responded in the low category; $17.9 \%$ of employees responded in the high category and $71.6 \%$ of employees responded in the very high category.

The results of the analysis indicate that the Regents's transactional leadership style in running the Government and development of the Pohuwato Regency in Gorontalo Province is categorized as high or good. The height or quality of the transactional leadership style is strongly influenced by the passive management bye dimension. The low transactional leadership style is strongly influenced by the dimensions of laizes fairez.

Regent's Performance

TABLE 5. REGENT'S PERFOMANCE SCORE CATEGORIZATION

\begin{tabular}{ccc}
\hline Category & Frequency & Percentage \\
\hline Very High & 81 & 60 \\
High & 47 & 35 \\
Low & 4 & 3 \\
Very High & 2 & 2 \\
Total & 134 & $100 \%$ \\
\hline
\end{tabular}

Table 5 is data on employee perceptions regarding the performance of the Regent. The data shows that $2 \%$ of employees consider the Regent's Performance to be in the very low category, $3 \%$ of employees consider the Regent's Performance to be in low category, $35 \%$ of employees consider the Regent's Performance to be in high category and $60 \%$ of employees consider the Regent's Performance to be categorized very high. This data confirms that in general the performance of the Pohuwato District Head in running government and development is categorized as very high and high.

The Regent's performance can be traced through aspects of input, process, and output that can be seen visually in the following table.

\section{TABLE 6. DATA PERCENTAGE PERFORMANCE OF} REGENTS

\begin{tabular}{lllll}
\hline \multirow{2}{*}{ Aspect } & \multicolumn{4}{c}{ Percentage } \\
\cline { 2 - 5 } & Very & High & Low & Very \\
& High & & & Low \\
Input & 78,4 & 20,1 & 0 & 1,5 \\
Proses & 56,7 & 38,1 & 3,7 & 1,5 \\
Output & 66,4 & 26,1 & 3,7 & 1,5 \\
\hline
\end{tabular}
related to the Regent's performance on aspects of input, process, and output. Employee perception data related to the Regent's performance on the input aspect shows that $1.5 \%$ of employees respond in the very low category; $20.1 \%$ of employees responded in the high category, and $78.4 \%$ of employees responded in the very high category. In the process aspect shows that $1.5 \%$ of employees respond in the very low category; $3.7 \%$ of employees responded in the low category; $38.1 \%$ of employees responded with a high category, and $56.7 \%$ of employees responded with a very high category. In the output aspect shows that $1.5 \%$ of employees respond in the very low category; 6\% of employees responded in the low category; $26.1 \%$ of employees responded in the high category and $66.4 \%$ of employees responded in the very high category.

The results of the analysis show that the Regent's performance in running the Government and development of Pohuwato Regency in Gorontalo Province is categorized as very high or good. The high or good performance of the Regent is strongly influenced by three dimensions, but the dimension of input has a greater influence on performance. Nevertheless, the low performance of the Regent was strongly influenced by the output aspect.

\section{Discussion}

1) Transformational Leadership Style. The results showed that the Regent's transformational leadership in running the Government and development of the Pohuwato Regency in Gorontalo Province was very high. Descriptive analysis data shows that high employee perceptions related to the percentage of Regent's transformative leadership style cannot be separated from attitudes and behaviors especially in aspects of inspiration motivation, charisma, individualized 
consideration and intellectual stimulation in running the government in Pohuwato District, Gorontalo Province.

The results of the analysis (table 2) show that the Regent's transformational leadership style is very good in carrying out the governance and development of Pohuwato Regency in Gorontalo Province. High or good transformational leadership style is strongly influenced by the dimensions of inspiration motivation, regarding planning with subordinates and charismatic dimensions of self-confidence in change. However, the aspects of individualized consideration and intellectual stimulation are still not good according to employee responses.

Transformational leadership as a leadership style that leads to increased awareness of shared interests among members of the organization and also helps them in achieving their collective goals [19], [20]. Transformational leadership style concentrates on the development and needs of their followers [21]-[23]. This opinion shows that the attitude of transformational leaders leads to an increase in human resources to achieve common goals.

Transformational leadership style stimulates and transforms, creates positive change, puts enthusiasm and energy into everything, followers where they take care of each other's interests and act in the interests of the group as a whole to achieve extraordinary results [24] Organizations around the world give top priority to innovation, because this leads them to be successful in the long term. The development of intellectual stimulation culture is now important for organizations to maintain their competitive position and sustainability. The attitude of innovation can improve efficiency because this brings breakthroughs in the traditional way of working, intellectual stimulation culture not only brings innovation and gradual change in ways of thinking and doing business activities, but it greatly influences people's behavior [25].

2) Transactional leadership style. The results of the analysis (table 4) show that the Regent's transactional leadership is in the high category. The high perception of employees regarding the percentage of the Regent's transactional leadership style cannot be separated from the attitudes and behaviors shown in the contingent reward aspect, laissez-faire, active management by exception and passive management bye exceptions in running the government. Transactional leadership as a contingent reward explains the extent to which effective transactions and exchanges are arranged between leaders and followers. Transactional leadership is centered on follower exchange leadership. Employees or even work by the will and direction of the leader. The basis of employees or even work is a reward that can be negative as a punishment.

Transactional leadership occurs through exchanges between leaders and followers where rewards and incentives are offered in exchange for effort and compliance. Transactional leaders see relationships with followers as an exchange process in which their role is to establish and obtain the consent of followers by clarifying rewards that are likely to be achieved in exchange for a satisfying
Regent's performance. Transactional leadership occurs through exchanges between leaders and followers where rewards and incentives are offered in exchange for effort and compliance. Management with exceptions refers to the behavior of leaders who are often involved in corrective transactions with followers.

The application of the concept of leadership, both transactional leadership, and transformational leadership, is expected to increase the role of followers to do work in line with expectations. Transactional leadership and transformational leadership are carried out simultaneously for the achievement of goals or tasks. The application of transactional leadership and transformational leadership can increase motivation, job satisfaction, commitment, to improve performance.

Regent's Performance. The results of the analysis (table 6) show that the performance of the Pohuwato District Head in running government and development is very high or very good. The statement was supported by the findings of the descriptive analysis which showed that the high perception of employees related to the percentage of the performance of the Regent could not be separated from the aspects of input, process, and output that were achieved in running the government. However, the dimension of input is that which has a greater influence on the high achievement of the Regent's performance. Furthermore, the low performance of the Regent was greatly influenced by the low quality of the aspects

Furthermore, measuring the performance of public services of government agencies is very important to ensure that governance runs well. Performance is the work quality and quantity achieved by an employee in carrying out their duties in accordance with the responsibilities assigned to him. More specifically, it is stated that the performance of the Regional Government is the achievement of the implementation of regional government affairs (Government Regulation of the Republic of Indonesia No. 6 of 2008). Previous statements indicate that the performance of local governments can be seen from the achievements obtained by one regional apparatus in carrying out the governance process both in quality and quantity.

A Mandate for Strategic Planning and Performance Measurement. This opinion shows that performance measurement/assessment is a management tool to improve the quality of decision making and accountability. Continuous performance measurement will provide feedback so that constant improvement effort is objectively achieved in a specified period. Performance appraisal is one of the critical factors for developing an organization effectively and efficiently. The existence of a work performance assessment policy or program means that the organization has made good use of existing human resources in the organization.

The performance of leaders in a complex environment is the key to operating an organizational system. Leader skills and ability to influence followers can affect organizational performance. Cognitive and affective in leaders mediate the 
relationship between leader behavior and the psychological state of the team which, in turn, encourages team performance

\section{CONCLUSION}

The results of the descriptive analysis for each variable and aspect of the constituent variables confirm that the transformational leadership style has the highest percentage, followed by the Regent's performance, then the transactional leadership style. Other findings from this study indicate that the combination of these two leadership styles has proven useful in carrying out government tasks. Subsequent research can continue this research by increasing the level of analysis such as partial and simultaneous regression analysis.

\section{ACKNOWLEDGMENT}

The writer would like to express their thanks to all parties, especially for the reviewer team who have provided valuable suggestion and guidance in writing this article

\section{REFERENCES}

F. Chairunisa, M. T. Malik, dan M. A. Rahman, "ContextualParticipative e-Government Implementation Model: A Case Study of the Office of Demographic and Citizen Data Records of Makassar," Mediterr. J. Soc. Sci., vol. 7, no. 1 S1, hal. 345, 2016.

[2] P. M. Senge, Leading learning organizations: The bold, the powerful, and the invisible. Center for Organizational Learning, Massachusetts Institute of Technology Cambridge, MA, 1996.

[3] Hernawan, R. Salam, Haerul, dan Suprianto, "Regional Council Role in the Welfare Society Program," vol. 149, no. Icest, hal. 31-33, 2017

[4] J. Abdussamad, H. Akib, dan J. Paramata, "Effect of Transformational Leadership And Organizational Culture on Employee Performance Toward The Department of Education, Youth and Sports Gorontalo Province, Indonesia," Int. J. Acad. Res., vol. 7, no. 1, 2015.

[5] J. Papilaya, T. R. Soisa, dan H. Akib, "The Influence of Implementing the Strategic Policy in Creating Business Climate, Business Environment and Providing Support Facilities towards Business Empowerment on Small Medium Craft enterprises in Ambon Indonesia," Int. Rev. Manag. Mark., vol. 5, no. 2, hal. 85-93, 2015.

[6] H. Mokat, J. Erna, L. Lumingkewas, R. Rifdan, A. I. Kesuma, dan A. I. Kesuma, "The Leadership Style of Woman as the Head of Regency in Instructing Duties and Supervision to Subordinates (The Case Study in Minahasa Tenggara Regency)," Int. J. Humanit. Soc. Sci. Invent., vol. 4, no. 8, hal. 1-8, 2015.

[7] J. E. Bono, A. C. Hooper, dan D. J. Yoon, "Impact of rater personality on transformational and transactional leadership ratings," Leadersh. Q., vol. 23, no. 1, hal. 132-145, 2012.

[8] C.-Y. Lai, J. S.-C. Hsu, dan Y. Li, "Leadership, regulatory focus and information systems development project team performance," Int. J. Proj. Manag., vol. 36, no. 3, hal. 566-582, 2018.

[9] S. Kang dan P. G. Svensson, "Shared leadership in sport for development and peace: A conceptual framework of antecedents and outcomes," Sport Manag. Rev., 2018.

[10] J. Li dan B. Yuan, "Both angel and devil: The suppressing effect of transformational leadership on proactive employee's career satisfaction," Int. J. Hosp. Manag., vol. 65, hal. 59-70, 2017.

[11] Ü. Alnıaçık, E. Alnıaçık, K. Akçin, dan S. Erat, "Relationships Between Career Motivation, Affective Commitment and Job Satisfaction," Procedia - Soc. Behav. Sci., vol. 58, hal. 355-362, 2012. between corporate social responsibility, job satisfaction, and organizational commitment: Case of Pakistani higher education," J. Clean. Prod., vol. 142, hal. 2352-2363, 2017.

[13] E. G. Lambert, K. I. Minor, J. B. Wells, dan N. L. Hogan, "Social support's relationship to correctional staff job stress, job involvement, job satisfaction, and organizational commitment," Soc. Sci. J., vol. 53, no. 1, hal. 22-32, 2016.

[14] C. Jaworski, S. Ravichandran, A. C. Karpinski, dan S. Singh, "The effects of training satisfaction, employee benefits, and incentives on part-time employees' commitment," Int. J. Hosp. Manag., vol. 74, hal. 1-12, 2018.

[15] A. P. Mangkunegara, "Profesionalisme Karyawan," Jakarta Raja Graf. Persada, 2001.

[16] J. B. Whittaker, Government Performance and Results Act of 1993. Educational Services Institute, 1995.

[17] R. B. Denhardt dan J. V Denhardt, "The new public service: Serving rather than steering," Public Administration Review, vol. 60, no. 6. hal. 549-559, 2000.

[18] A. Sanusi, "Government Reorganization to Improve Public Services: A lesson from some Indonesia local governments."

19] B. J. Avolio dan B. M. Bass, "Individual consideration viewed at multiple levels of analysis: A multi-level framework for examining the diffusion of transformational leadership," Leadersh. Q., vol. 6, no. 2, hal. 199-218, 1995.

[20] F. J. Yammarino dan B. M. Bass, "Person and situation views of leadership: A multiple levels of analysis approach," Leadersh. Q., vol. 2, no. 2, hal. 121-139, 1991.

[21] G. G. Cummings et al., "Leadership styles and outcome patterns for the nursing workforce and work environment: A systematic review," Int. J. Nurs. Stud., vol. 85, hal. 19-60, 2018.

[22] Y. Xie et al., "Leadership style and innovation atmosphere in enterprises: An empirical study," Technol. Forecast. Soc. Change, 2018.

[23] I. Rouine, "Target country's leadership style and bidders' takeover decisions," Int. Rev. Financ. Anal., 2018.

[24] J. Malen dan P. M. Vaaler, "Organizational slack, national institutions and innovation effort around the world," J. World Bus., vol. 52, no. 6, hal. 782-797, 2017.

[25] M. Hamdoun, C. J. Chiappetta Jabbour, dan H. Ben Othman, "Knowledge transfer and organizational innovation: Impacts of quality and environmental management," J. Clean. Prod., vol. 193, hal. 759-770, 2018. 